\title{
GAMBARAN ANTENATAL CARE (ANC) DAN VAKSINASI COVID-19 PADA IBU HAMIL
}

\author{
Lia Aria Ratmawati, Dewie Sulistyorini \\ Politeknik Banjarnegara \\ email : liaaria13@gmail.com,
}

Riwayat Artikel: Diterima: 12 November 2021, direvisi: 25 November 2021, dipublikasi: 29 November 2021

\begin{abstract}
Guidelines for antenatal care for pregnant women in the era of the Covid-19 pandemic include screening for risk factors. Pregnant women are expected to understand and use the contents of the $\mathrm{MCH}$ Handbook. Efforts are also being made to vaccinate pregnant women with COVID-19 to protect mothers and babies from the effects of the risk of Covid-19 infection. The purpose of the study was to describe antenatal care and covid-19 vaccination for pregnant women. The methodology used is a qualitative research type with an exploratory approach. The type of data used is primary data by collecting 8 respondents from pregnant women, 8 husbands and 1 midwife. Data collection is done by sharing a google form link. The results of the study, during the Covid-19 period, mothers carried out routine pregnancy checks according to their trimesters. Pregnant women study and apply MCH books in their daily lives. Participate in face-to-face classes for pregnant women by wearing a mask. P4K stickers have been filled in by pregnant women. The mother also did a pregnancy check by the doctor at the Puskesmas. Before the antenatal visit, the mother had made an appointment. Pregnant women have been vaccinated against covid-19. Conclusion: antenatal care carried out by pregnant women has changed and mothers have vaccinated against covid-19 to protect themselves and their fetuses.
\end{abstract}

Keywords: antenatal care; COVID-19; vaccination

\begin{abstract}
ABSTRAK
Pedoman pemeriksaan kehamilan untuk ibu hamil di era pandemi Covid-19 meliputi skrining faktor risiko. Ibu hamil diharapkan memahami dan menggunakan isi Buku KIA. Upaya juga dilakukan untuk memvaksinasi ibu hamil dengan COVID-19 untuk melindungi ibu dan bayi dari efek risiko infeksi Covid-19. Tujuan penelitian adalah menggambarkan antenatal care dan vaksinasi covid-19 pada ibu hamil. Metodologi yang digunakan jenis penelitian kualitatif dengan pendekatan eksploratif. Jenis data yang digunakan adalah data primer dengan mengumpulkan dari 8 responden ibu hamil, 8 orang suami dan 1 orang bidan. Pengumpulan data dilakukan dengan membagi link google form. Hasil penelitian, di masa COVID-19 ibu melakukan pemeriksaan hamil secara rutin sesuai trimesternya. Ibu hamil mempelajari dan menerapkan buku KIA dalam kehidupan sehari-hari. Mengikuti kelas ibu hamil secara tatap muka dengan menggunakan masker. Stiker P4K sudah dilakukan pengisian oleh ibu hamil. Ibu juga melakukan pemeriksaan kehamilan oleh dokter di Puskesmas. Sebelum melakukan kunjungan antenatal ibu sudah membuat janji terlebih dahulu. Ibu hamil sudah mendapatkan vaksinasi COVID-19. Kesimpulan adalah pemeriksaan kehamilan yang dilakukan ibu hamil mengalami perubahan dan ibu melakukan vaksinasi covid-19 untuk melindungi diri dan janinnya.
\end{abstract}

Kata Kunci: peneriksaan kehamilan; COVID-19; vaksinasi 


\section{Pendahuluan}

Coronavirus merupakan golongan virus yang dapat mengakibatkan penyakit dengan gejala ringan sampai berat. Dewasa ini ada dua jenis virus corona yang disinyalir mampu mengakibatkan timbulnya penyakit dengan menimbulkan gejala berat seperti Middle East Respiratory Syndrome (MERS) dan Severe Acute Respiratory Syndrome (SARS). Coronavirus disease 2019 (COVID19) merupakan jenis penyakit baru yang belum pernah ditemukan pada manusia yang muncul pada tahun 2019. Virus penyebab COVID19 adalah SarsCoV2. Tanda dan gejala umum infeksi COVID-19 adalah sesak napas akut, seperti demam, batuk, dan sesak napas. Masa inkubasi rata-rata adalah 56 hari dan masa inkubasi terlama adalah 14 hari. Kasus COVID-19 yang parah dapat menyebabkan gangguan pada organ paru berupa pneumonia, sindrom gangguan pernapasan akut, gagal ginjal, dan bahkan kematian. Tanda dan gejala klinis yang dilaporkan adalah demam pada sebagian besar kasus dan sesak napas pada beberapa kasus, dan hasil pemeriksaan diagnostik dengan sinar- $X$ menunjukkan infiltrat pneumonia yang luas di kedua paru-paru(Kementrian Kesehatan RI, 2020b) Pandemi COVID 19 ini, menyebabkan pembatasan di hampir semua layanan rutin, termasuk layanan medis ibu dan bayi baru lahir. Misalnya, ibu hamil ragu untuk pergi ke puskesmas atau fasilitas medis lainnya karena takut tertular. Disarankan untuk menunda kehamilan dan kelas ibu hamil, dan tidak cukup siap untuk layanan personel dan infrastruktur, termasuk alat pelindung diri. Akibatnya, pelayanan kesehatan ibu dan bayi baru lahir merupakan salah satu pelayanan yang terkena dampak baik dari segi akses maupun kualitas (Kementrian Kesehatan RI, 2020a).

Masyarakat Indonesia kini harus mulai mengadaptasi kebiasaan baru untuk menjalani hidup sehat dalam menghadapi pandemi COVID-19. Kebiasaan baru perlu disesuaikan untuk membantu masyarakat kembali beraktivitas sehari-hari dan terhindar dari COVID-19. Hak masyarakat atas kesehatan dasar dapat diwujudkan melalui adaptasi dengan kebiasaan baru (Kementrian Kesehatan RI, 2020a).
Beberapa pedoman Antenatal care (ANC) bagi ibu hamil yang dapat dilakukan di masa Pandemi COVID19, yaitu: 1) Skrining faktor risiko pada ibu hamil dapat dilakukan ketika dating untuk pemeriksaan kehamilan pertama, seperti (risiko penularan HIV, sifilis dan hepatitis B). dari ibu ke anak / Pencegahan penularan HIV dari ibu ke anak (PPIA). Ibu hamil diarahkan untuk melakukan pemeriksaan ke dokter di fasilitas pelayanan kesehatan (fasyankes) dengan ketentuan ibu hamil tidak boleh menunggu lama. Jika ibu hamil datang kepada bidan tetap diberikan pemeriksaan ANC, setelah itu ibu akan dirujuk ke dokter 2) Ibu hamil diarahkan untuk dapat memahami dan menerapkan lebih optimal isi buku KIA dalam kehidupan sehari-hari, ketika ada keluhan atau tanda bahaya dalam kehamilan, ibu hamil harus segera pergi ke fasilitas kesehatan. 3) Selama masa pandemi COVID19, kelas ibu hamil ditiadakan sementara atau dapat diikuti secara online. 4) Penunjukan/pendaftaran jarak jauh untuk mempelajari faktor risiko dan gejala COVID19 serta mewajibkan pasien memakai masker saat mengunjungi fasilitas kesehatan (Kementrian Kesehatan RI, 2020a).

Ibu hamil berisiko lebih tinggi terkena penyakit serius saat tertular COVID-19, terutama pada ibu hamil dengan kondisi medis tertentu. Mengingat jumlah ibu hamil yang terinfeksi COVID-19 semakin meningkat, dan risiko ibu hamil yang semakin meningkat jika infeksi COVID-19 sudah parah dan menyerang ibu hamil dan anaknya, maka perlu dilakukan upaya untuk memvaksinasi ibu hamil dengan COVID-19. Komite Penasihat Nasional Ahli Imunisasi (ITAGI) juga telah merekomendasikan upaya untuk memvaksinasi ibu hamil terhadap COVID-19. Hal ini berdasarkan Surat Edaran Kementerian Kesehatan RI HK.02.01/I/2007/2021 tentang Vaksinasi COVID-19 Bagi Ibu Hamil dan Koordinasi Skrining Vaksinasi COVID-19 Bagi Ibu Hamil. Adapun tujuan penelitian ini menggambarkan ANC dan vaksinasi COVID-19 pada ibu hamil..

\section{Metode Penelitian}

Penelitian ini menggunakan metode kualitatif dengan pendekatan eksploratif. Tempat penelitian Puskesmas Banjarnegara 
1 Kabupaten Banjarnegara. Populasi adalah ibu hamil Trimester III yang berkunjung di Puskesmas Banjarnegara 1 di bulan Oktober 2021 sejumlah 73 ibu hamil. Sampel penelitian adalah ibu hamil Trimester III sebanyak 8 responden, dengan teknik sampling menggunakan purposive sampling. Kriteria inklusi meliputi bersedia menjadi responden, melakukan kunjungan kehamilan ke puskesmas, dan tempat tinggal berada di wilayah kerja Puskesmas Banjarnegara 1.

Jenis data yang digunakan adalah data primer. Data dikumpulkan dari 8 responden ibu hamil, 8 orang suami dan 1 orang bidan. Pada penelitian ini teknik pengumpulan data dilakukan dengan membagi link google form melalui Whatsapp. Responden diminta untuk mengisi kuesioner penelitian guna meminimalkan kontak langsung dan mencegah penyebaran COVID-19. Pengumpulan data dilaksanakan pada ibu hamil tentang ANC dan vaksinasi COVID-19 bagi ibu hamil. Pengumpulan data kepada suami dan bidan untuk memvalidasi informasi yang didapat dari ibu hamil. Validitas penelitian dilakukan dengan menggunakan triangulasi sumber. Data kemudian diolah secara manual. Analisis data dengan membandingkan informasi dari informan dengan teori yang ada, kemudian membuat matrik data dan menarik kesimpulan.

\section{Hasil dan Pembahasan}

\section{Gambaran ANC}

\section{Tema 1 : Kunjungan ANC Ibu Hamil}

Perawatan kehamilan adalah tentang pendidikan, promosi kesehatan, dan menemukan dan mengelola kelainan. Berdasarkan standar $\mathrm{WHO}$, ibu hamil dianjurkan untuk mengunjungi ANC setidaknya empat kali selama kehamilan. Waktu kunjungan terdiri dari satu kali pada semester pertama, satu kali pada semester kedua, dan dua kali pada semester ketiga. Sesuai standar pelayanan kebidanan, jadwal kunjungan ANC adalah sebagai berikut: Sebulan sekali, setiap dua minggu sekali pada semester pertama dan kedua, dan sekali seminggu pada semester ketiga (Kementrian Kesehatan RI, 2016).
Pernyataan ibu hamil:

"Saya periksa hamil untuk 1-3 bulan sebanyak 3 kali, saat 4-6 bulan 3 kali dan saat 7-9 bulan sebanyak 3 kali" (Bumil F). "Periksa hamil usia kehamilan 1-3 bulan 3 kali, usia 4-6 bulan 3 kali, usia 7-9 bulan 2 kali" (Bumil S).

Pernyataan suami:

"Istri saya periksa usia kehamilannya 1-3 bulan sebanyak 3 kali, saat 4-6 bulan 3 kali dan saat 7-9 bulan sebanyak 3 kali" (Suami $D S)$.

Pernyataan Bidan:

"Pemeriksaan kehamilan untuk trimester satu sebanyak 2 kali, untuk trimester dua sebanyak 1 kali dan untuk trimester tiga sebanyak 3 kali" (Bidan L).

ANC terhadap kehamilan normal pada masa adaptasi baru minimal $6 x$, dengan informasi tentang $2 \mathrm{x}$ dengan Trimester $1,1 \mathrm{x}$ dengan Trimester 2, dan $3 x$ dengan Trimester 3. (Kemenkes RI, 2020a). Hasil penelitian ini menunjukkan bahwa ibu hamil di Puskesmas Banjarnegara 1, pada masa pandemi COVID-19 tetap melaksanakan pemeriksaan kehamilan secara rutin, sesuai trimesternya, bahkan ada yang lebih. Seperti pada trimester 1 minimalnya 2 kali kunjungan, sedangkan responden menyampaikan 3 kali, begitu pula pada trimester 2 minimal 1 kali kunjungan, sedangkan responden menyampaikan 3 kali.

ANC pertama pada trimester 1 dilakukan untuk skrining faktor risiko oleh dokter dengan tetap menerapkan protokol kesehatan. Saat ibu pertama kali datang ke bidan, bidan akan melakukan pemeriksaan kehamilan seperti biasa kemudian dirujuk ke dokter untuk pemeriksaan. Sebelum kunjungan pribadi sebelum melahirkan, akan dilakukan janji temu skrining riwayat kesehatan/registrasi jarak jauh melalui media komunikasi (telepon)/online untuk mencari faktor risiko dan gejala COVID19.

ANC kedua pada trimester 1, ANC ketiga pada trimester 2, ANC keempat pada trimester 3, dan ANC keenam pada trimester 3 , dilaksanakan untuk tidak lanjutan berdasarkan hasil skrining. Sebelum wawancara pribadi, akan dilakukan janji temu/registrasi jarak jauh dengan pemeriksaan riwayat kesehatan melalui 
media komunikasi (telepon)/online untuk mencari faktor risiko dan gejala COVID19.

Pemeriksaan ANC kelima pada Trimester 3 dilakukan untuk skrining faktor risiko persalinan oleh dokter dengan menerapkan protokol kesehatan. Skrining dilakukan untuk menentukan faktor risiko persalinan, penentuan tempat lahir, dan apakah diperlukan rujukan terjadwal. Sebelum wawancara pribadi, akan dilakukan janji temu/registrasi jarak jauh dengan pemeriksaan riwayat kesehatan melalui media komunikasi (telepon)/online untuk mencari faktor risiko dan gejala COVID19. Jika gejala COVID19 terjadi, ibu dirujuk ke rumah sakit untuk pemeriksaan apusan. Jika akses ke rumah sakit rujukan sulit, akan dilakukan rapid test (Kementrian Kesehatan RI, 2020a).

Jenis pelayanan antenatal care sama seperti pada situasi normal (sesuai SOP), kecuali pemeriksaan USG untuk sementara ditangguhkan bagi ibu dengan PDP atau terkonfirmasi COVID-19 sampai masa karantina selesai. Setelah pemeriksaan lanjutan, ibu dianggap sebagai kasus berisiko tinggi (Kementrian Kesehatan RI, 2020c).

Rekomendasi WHO kunjungan ibu hamil selama pandemi COVID-19 dilakukan 2 kali Kunjungan wajib pertama selama trimester pertama dianjurkan oleh dokter untuk menyaring faktor risiko (HIV, sifilis, hepatitis B). Jika baru pertama kali ke bidan, setelah pemeriksaan kehamilan, ibu hamil akan dirujuk ke dokter untuk diperiksa. Kunjungan wajib kedua dilakukan oleh dokter pada trimester ke-3 (satu bulan sebelum tanggal jatuh tempo) untuk mempersiapkan persalinan. Sisa kunjungan dapat dilakukan atas saran profesional kesehatan dan sebelum membuat janji. Ibu hamil dianjurkan untuk mempelajari Petunjuk Penggunaan KIA. Jika memungkinkan, konseling kehamilan dan pendidikan kelas untuk ibu hamil dapat menggunakan aplikasi telemedicine (misalnya, teleCTG Sehati, Halodoc, Alodoc, Teman Hamil, dan lain-lain) dan Pendidikan Berkelanjutan melalui SMS Bunda (Kementrian Kesehatan RI, 2020c).

Temuan ini berbeda dengan penelitian (Tristanti \& Kulsum, 2021) menyampaikan bahwa pada masa pandemi ibu hamil tidak melakukan pemeriksaan kehamilan secara teratur. Penelitian lainnya, didapatkan hasil perilaku antenatal care ibu hamil di masa pandemi COVID-19 memberikan keseimbangan yang hampir seimbang antara perilaku positif 21 responden $(52,5 \%)$ dan perilaku negatif hingga 19 responden $(47,5 \%)$. Sebagian besar perilaku ibu hamil berdasarkan pedoman pelaksanaan antenatal care selama pandemi COVID19 adalah negatif dengan 24 responden atau $60 \%$ (Refiani et al., 2021).

\section{Tema 2 : Mempelajari dan menerapkan buku KIA dalam kehidupan sehari-hari}

Ibu hamil wajib mempelajari buku KIA dan menggunakannya dalam kehidupan sehari-hari. Kenali tanda-tanda bahaya selama kehamilan. Ibu hamil harus segera melapor ke layanan kesehatan jika terjadi keluhan atau peringatan. Ibu hamil perlu memeriksakan kondisi dan pergerakan janinnya. Untuk tanda risiko/risiko (dijelaskan dalam manual KIA), mual dan muntah berlebihan, perdarahan hebat, gerakan janin menurun, ketuban pecah, sakit kepala berat, tekanan darah tinggi, persalinan dan serangan berulang, atau diabetes gestasional. riwayat preeklamsia, preeklamsia berat, janin kerdil, ibu hamil dengan penyakit penyerta lain atau satu riwayat bersalin yang buruk, ibu harus memeriksakan diri ke fasilitas medis (Kementrian Kesehatan RI, 2020a).

Pernyataan ibu hamil:

"Ya, saya baca buku KIA,karna untuk menjdi panduan ibu hamil dan memberikan pengertian untuk saya yg blm memahaminya" (Bumil SS).

"Ya baca, bisa lebih waspada dan selalu menjaga kesehatan" (Bumil J).

Pernyataan suami:

"Istri saya baca buku KIA yang dari bu bidan" (Suami SR).

Pernyataan Bidan:

"Ya ibu hamil harus baca buku KIA, karena banyak informasi mengenai kehamilan baik ketidaknyamanan ataupun tanda bahaya yang ada solusinya di buku KIA tanpa harus bertemu langsung dengan bidan untuk mengurangi kontak langsung di masa pandemi" (Bdn L). 
Berdasarkan pernyataan responden, dapat kita simpulkan bahwa selama masa Pandemi COVID-19, ibu hamil tetap membaca dan menerapkannya pada kehidupan sehari-hari. Buku KIA berisi informasi lengkap seputar kehamilan, persalinan, nifas, bayi dan balita, mulai dari informasi tentang kondisi yang normal, sampai mendeteksi adanya tanda bahaya. Membaca buku KIA dapat meminimalkan dampak kurang informasi tentang kesehatan ibu dan anak akibat pembatasan akses selama masa Pandemi COVI-19.

Ibu hamil harus bisa merasakan pergerakan janin sejak minggu ke-20 kehamilan. Setelah usia kehamilan 28 minggu, gerakan janin dihitung secara mandiri (setidaknya 10 gerakan dalam 2 jam). Jika 2 jam pertama gerakan janin tidak mencapai 10 gerakan, pemantauan dapat diulang untuk 2 jam berikutnya, hingga 6 kali (dalam 12 jam). Jika tidak ada 10 gerakan dalam waktu 12 jam, ibu harus segera datang ke fasilitas kesehatan untuk memastikan kesejahteraan janin. Ibu hamil selalu menjaga kesehatannya melalui pola makan yang seimbang dan bergizi, menjaga kebersihan diri, dan melanjutkan aktivitas fisik mandiri berupa senam ibu hamil/yoga/pilates/ stretching di rumah. Wanita hamil terus mengonsumsi Tablet Penambah Darah (TTD) berdasarkan dosis yang diberikan oleh profesional kesehatan (Kementrian Kesehatan RI, 2020a).

Penelitian (Sistiarani et al., 2014) melaporkan bahwa ada hubungan fungsi pencatatan buku KIA dengan Ibu memiliki pengetahuan tentang $\mathrm{KIA}$, tetapi fungsi edukatif dan komunikatif buku KIA tidak berhubungan dengan pengetahuan KIA. Ibu dengan pengetahuan KIA baik dengan fungsi pembukuan KIA tidak lengkap sekitar $70 \%$, dibandingkan dengan ibu dengan fungsi pembukuan KIA lengkap sekitar 45,1\%, perbedaannya signifikan secara statistik dengan $p$ value $=0,031$ ( $p$-value 0,05$)$ yang berarti ada hubungan antara fungsi pembukuan KIA dengan pengetahuan KIA

Penelitian (Hanum \& Safitri, 2018), menunjukkan hasil uji statistik menggunakan chi-square menunjukkan nilai $\mathrm{p}=0,001$. Disini kami menyimpulkan bahwa ada keterkaitan antara $p<(0,001 \&$ It; 0,05$)$ dengan demikian pengetahuan ibu hamil dan pemanfaatan buku kesehatan ibu dan anak
(KIA) di wilayah kerja Puskesmas Namukl. Anda dapat melampirkannya. Sikap positif ibu terhadap buku "Kesehatan Ibu dan Anak" (KIA) bersumber dari informasi yang diperoleh dari buku "Kesehatan lbu dan Anak" (KIA) yang merupakan salah satu faktor predisposisi pola asuh yang baik. Sikap ibu terhadap buku kesehatan ibu dan anak (KIA) secara langsung dipengaruhi oleh pengetahuan ibu tentang pentingnya menggunakan buku kesehatan ibu dan anak (KIA). Sikap yang dibentuk dengan pengetahuan mempengaruhi perilaku manusia (Mahayati et al., 2013)

Tema 3: Keikutsertaan kelas ibu hamil secara on line

Zona hijau (tidak terpengaruh/uncased) dapat melaksanakan kelas ibu hamil secara langsung (maksimal 10 peserta) dan harus menjalankan protokol kesehatan secara ketat. Zona kuning (risiko rendah), oranye (risiko sedang), dan merah (risiko tinggi) ditunda selama pandemi COVID-19 atau melalui media komunikasi online (video call, Youtube, Zoom) (Kementrian Kesehatan RI, 2020a).

Pernyataan ibu hamil:

"Ya, ikut kelas ibu hamil secara tatap muka, dengan menggunakan prokes memakai masker" (Bumil R).

"Ya baca, bisa lebih waspada dan selalu menjaga kesehatan" (Bumil J).

Pernyataan suami:

"Ikut kelas ibu hamil langsung (tatap muka) dengan pakai masker" (Suami YM).

Pernyataan Bidan:

"Ya, dilakukan kelas ibu hamil untuk pemantauan ibu hamil dan memberikan informasi seputar kehamilan khususnya ibu hamil risiko tinggi. Kelas ibu hamil dilakukan secara tatap muka dengan prokes memakai masker" (Bdn L).

Informan menyampaikan, bahwa tetap mengikuti kelas ibu hamil dengan menggunakan protokol kesehatan, memakai masker. COVID-19 dapat ditularkan melalui kontak dekat dan tetesan, bukan di udara. Orang-orang yang melakukan kontak dekat atau merawat pasien COVID19 memiliki 
risiko infeksi terbesar. Pencegahan dan mitigasi merupakan kunci implementasi dalam pelayanan kesehatan dan masyarakat. Beberapa tindakan pencegahan yang paling efektif di masyarakat meliputi: Praktikkan hand sanitizer dengan hand sanitizer saat tangan tidak terlihat kotor, atau cuci tangan pakai sabun saat tangan terlihat kotor, hindari kontak mata, hidung, dan mulut. Tutup hidung dan mulut dengan lengan atas atau bagian dalam sapu tangan, gunakan label batuk atau bersin, dan buang sapu tangan ke tempat sampah. Kenakan masker medis untuk masalah pernapasan dan lakukan kebersihan tangan setelah melepas masker. Jaga jarak (minimal $1 \mathrm{~m}$ ) dari orang dengan gangguan pernapasan (Kementrian Kesehatan RI, 2020b).

Penelitian Lucia, dkk (2015) menunjukkan bahwa nilai rata-rata berdasarkan kinerja kelas kehamilan pre-test adalah 43,83, dengan perbedaan yang signifikan setelah kinerja kelas kehamilan (post-test) 48,47 ( $p=0,000<0,05$ ). Pada intinya penyelenggaraan kursus untuk ibu hamil akan mempengaruhi pengetahuan tentang persiapan persalinan di Puskesmas Tanoyan Kecamatan Boraan Mongondourency Kabupaten Lorayan (Lucia et al., 2015).

\section{Tema 4 : Pengisian Stiker P4K}

Untuk wilayah yang masuk zona hijau (tidak terdampak / tidak ditemukan kasus) pengisian stiker P4K dilakukan oleh tenaga kesehatan pada saat ibu hamil mendapatkan pelayanan antenatal. Wilayah yang masuk kategori zona kuning (risiko rendah), orange (risiko sedang), merah (risiko tinggi) pengisian stiker $\mathrm{P} 4 \mathrm{~K}$ dilakukan oleh ibu hamil secara mandiri atau keluarga yang dipandu oleh bidan/perawat/dokter melalui media komunikasi (Kementrian Kesehatan RI, 2020a).

Pernyataan ibu hamil:

"Stiker sudah diisi oleh saya sendiri" (Bumil $F)$.

Pernyataan suami:

"Ya, sudah diisi" (Suami DS)

Pernyataan Bidan:

"Ya sudah disi, pengisian stiker P4K dilakukan oleh ibu dan bidan" (Bdn L).
Hasil penelitian menunjukkan hasil uji chi square diperoleh nilai $p=0,000$. Hal ini dapat disimpulkan bahwa ada hubungan tingkat pendidikan dengan pengetahuan ibu mengenai stiker P4K (Aliyanto \& Rosmadewi, 2017).

Tema 5 : Pemeriksakan kehamilan ke dokter selama pandemi

Pemeriksaan kehamilan pertama pada trimester 1, bertujuan untuk deteksi faktor risiko yang dilakukan oleh dokter dengan menerapkan protokol kesehatan. Apabila ibu hamil datang untuk kunjungan pertama, bidan tetap melakukan pelayanan antenatal sesuai prosedur, selanjutnya ibu hamil di rujuk ke dokter untuk dilakukan skrining. Pemeriksaan kehamilan kelima pada trimester 3 , seperti pelaksanaan scrining pada trimester 1, skrining faktor risiko persalinan dilakukan oleh Dokter dengan menerapkan protokol kesehatan. Skrining faktor risiko persalinan bertujuan untuk menetukan faktor risiko persalinan, menentukan rencana tempat persalinan, dan menentukan kebutuhan tindakan rujukan terencana atau tidak (Kementrian Kesehatan RI, 2020a).

Pernyataan ibu hamil:

"Ya, saya sudah periksa ke dokter di puskesmas" (Bumil WH).

"lya betul, saya periksa ke dokter Puskesmas saat awal kehamilan" (Bumil EL).

Pernyataan suami:

"Ya, istri juga periksa ke dokter" (Suami YM). "Istri saya periksa ke dokter di Puskesmas saat hamil muda" (suami MR).

Pernyataan Bidan:

"Ibu juga dianjurkan periksa ke dokter yang ada di puskesmas" (Bdn L).

Praktiknya ibu hamil sudah diperiksa oleh Dokter ketika kunjungan ANC awal kehamilan, hal tersebut sudah sesuai dengan pedoman pelayanan antenatal pada masa Pandemi COVID-19. Skrining faktor risiko untuk masalah kesehatan seperti penyakit menular dan tidak menular, kondisi kejiwaan, termasuk pemeriksaan diagnostik USG oleh Dokter, dilaksanakan pada 
Trimester 1. Pelaksanaan skrining sesuai dengan Pedoman ANC Terpadu dan panduan Buku KIA. Pemeriksaan ANC 2,3,4 dan 6 dapat dilakukan di FKTP oleh dokter atau bidan, jika dalam pemeriksaan pertama tidak ditemukan faktor risiko, atau ditemukan factor risiko namun masih bisa dikelola di FKTP. Ibu hamil yang terdeteksi memiliki factor risiko yang tidak bisa dikelola di FKTP, maka harus dilakukan rujukan sesuai dengan hasil skrining. Setelah rujukan akan mendapatkan pengelolaan secara menyeluruh (kemungkinan membutuhkan penanganan spesialistik selain oleh Dokter Sp.OG) (Kementrian Kesehatan RI, 2020a).

Penelitian Novitasari (2017) yang berjudul analisis pelaksanaan ANC terpadu dalam ketepatan deteksi dini penyakit penyerta kehamilan di puskesmas Imogiri 1 Bantul Daerah Istimewa Yogyakarta disampaikan bahwa pemeriksaan oleh dokter umum didahului dengan pengkajian yang disesuaikan dengan format yang sudah ada, tahapan selanjutnya dokter melakukan pemeriksaan fisik kemudian memberikan KIE sesuai temuan hasil pemeriksaan secara umum, hasil tes dan hasil tes bidan. Dokter bertanya kepada ibunya tentang rencana persalinannya dan menyatakan bahwa Hbnya normal sebagai prasyarat untuk melahirkan dengan bidan. Oleh karena itu, sebaiknya dilakukan setiap bulan untuk meningkatkan kadar $\mathrm{Hb}$ dan pola makan ibu hamil. Dokter juga menjelaskan risiko tetap rendah sampai sesaat sebelum melahirkan (Novitasari, 2017).

Tema 6 : Membuat janji terlebih dahulu sebelum memeriksakan kehamilan

Pada masa pandemi, ketika ibu hamil perlu melakukan kunjungan antenatal secara langsung maka dilakukan kontrak waktu/teleregistrasi dengan melakukan skrining anamnesa melalui media komunikasi (telepon)/ secara daring untuk mencari faktor risiko dan gejala COVID-19. Ketika hasil skrining secara daring dicurigai ada gejala mengarah ke COVID-19, ibu hamil dirujuk ke RS untuk dilakukan swab atau apabila tidak memungkinkan untuk mengakses RS Rujukan maka langkah yang ditempuh adalah dilakukan Rapid Test. Pemeriksaan skrining faktor risiko kehamilan dilakukan di RS Rujukan. Ketika tidak ditemukan gejala COVID-19, maka bisa langsung dilakukan skrining oleh Dokter di FKTP (Kementrian Kesehatan RI, 2020a).

Pernyataan ibu hamil:

"Ya, sudah janjian terlebih dahulu" (Bumil AN).

Pernyataan suami:

"sudah janjian sebelum periksa" (Suami DS)

Pernyataan Bidan:

"Ya, untuk membatasi jumlah ibu hamil agar tidak terjadi kerumunan dan penerapan protokol kesehatan, serta optimalisasi pelayanan kepada ibu hamil agar bisa mendapatkan pelayanan yg maksimal" (Bdn $L)$.

Informan menyatakan bahwa sebelum periksa hamil, sudah melakukan kontrak waktu dengan tenaga kesehatan, artinya ibu hamil sudah mengikuti prosedur untuk periksa hamil sesuai dengan rekomendasi pelayanan maternal pada masa pandemi COVID-19. Reservasi/registrasi jarak jauh adalah pendaftaran dengan fasilitas medis untuk kunjungan prenatal, postnatal, dan neonatus melalui media komunikasi (telepon/SMS/WA) atau online Saat membuat janji temu/registrasi jarak jauh, pihak berwenang harus menanyakan tanda, gejala, dan faktor risiko COVID-19 dan menekankan penggunaan masker saat pasien masuk ke fasilitas medis (Kementrian Kesehatan RI, 2020a).

\section{Gambaran vaksinasi COVID-19 pada ibu Hamil}

Kehamilan menjadi salah satu kondisi yang memiliki risiko tinggi apabila terpapar dengan. Dilaporkan dalam beberapa waktu terakhir bahwa sejumlah ibu hamil yang terkonfirmasi positif COVID -19 menjunjukkan gejala yang berat bahkan berakhir dengan meninggal dunia. Kondisi ini dikaitkan dengan teori bahwa kehamilan menyebabkan penurunan daya tahan tubuh secara fisiologis (immunocompromised) untuk menjaga kestabilan proses kehamilan. Oleh karena itu untuk membentengi ibu hamil dan janin dari infeksi COVID-19, Kementerian Kesehatan Republik Indonesia menetapkan ibu hamil sebagai salah satu sasaran utama penerima vaksinasi 
COVID-19 (RSUP Sarjito, 2021).

Kebijakan pemberian vaksinasi

COVID-19 pada ibu hamil juga telah direkomendasikan oleh Komite Penasihat Ahli Imunisasi Nasional (ITAGI). Dimana kebijakan ini dikuatkan dengan diterbitkannya Surat Edaran HK.02.01///2007/2021 tentang Vaksinasi COVID-19 Bagi Ibu Hamil. Perhimpunan Obstetri dan Ginekologi Indonesia (POGI) merekomendasikan vaksin COVID-19 aman untuk ibu hamil. Menurut rekomendasi untuk ibu menyusui, ibu hamil akan menjadi salah satu penerima vaksinasi COVID-19 (RSUP Sarjito, 2021).

Pernyataan ibu hamil:

"Belum vaksin, Karna punya riwayat penyakit bronhiris sama ginjal" (Bumil J).

"Sudah vaksinasi covid 19 untuk ibu hamil kemarin" (Bumil S).

Pernyataan suami:

"Belum vaksinasi, istri saya punya riwayat peyakit ginjal dan takut" (Suami MI). "Sudah vaksin saat hamil" (suami Y).

Pernyataan Bidan:

"Untuk melindungi ibu hamil dan bayinya dari resiko terkena covid-19” (Bdn L).

Ibu hamil sudah mendapatkan vaksinasi COVID-19, namun ada pula yang belum mendapatkan vaksinasi COVID-19, karena ada penyakit penyerta. Surat edaran Kemenkes RI No HK.02.01/I/2007/2021 tentang Vaksinasi COVID-19 Bagi Ibu Hamil dan Penyesuaian Skrinning Dalam Pelaksanaan Vaksinasi COVID-19, menjelaskan bahwa kebijakan vaksinasi yang diperuntukkan bagi ibu hamil masuk dalam kriteria khusus, oleh karena itu proses skrining atau tahap penapisan terhadap status kesehatan sebelum dilakukan pemberian vaksinasi dilakukan lebih detail dibandingkan dengan sasaran lain. Selain itu ibu hamil yang memiliki penyakit penyerta diwajibkan untuk konsultasi dan melampirkan surat rekomendasi dari dokter kebidanan dan kandungan terlebih dahulu sebelum dilakukan vaksinasi. Tujuan kebijakan ini adalah untuk dapat memastikan ibu hamil lebih aman jika dilakukan vaksinasi dan tidak memberikan efek samping pada penyakit penyerta yang diderita (RSUP Sarjito, 2021).
Dosis pertama vaksin COVID-19 untuk ibu hamil diberikan pada akhir kehamilan dan dosis kedua diberikan sesuai interval dan jenis vaksin. Vaksinasi COVID-19 untuk ibu hamil berlaku untuk usia kehamilan 13-33 minggu. Vaksinasi dikaitkan dengan proses organogenesis dan diberikan ketika masa kehamilan melebihi 13 minggu untuk meminimalkan efek pada janin. Diberikan sebelum usia 33 tahun untuk melindungi ibu saat melahirkan dan memungkinkan janin mentransfer antibodi ke rahim (RSUP Sarjito, 2021).

\section{Kesimpulan}

ANC selama COVID19 diadakan dengan memperhatikan upaya pencegahan penularan COVID-19 bagi ibu, bayi, dan profesional kesehatan. Di masa COVID-19 ibu melakukan pemeriksaan hamil secara rutin sesuai trimesternya; ibu hamil mempelajari dan menerapkan buku KIA dalam kehidupan sehari-hari; mengikuti kelas ibu hamil secara tatap muka dengan menggunakan masker; stiker P4K sudah dilakukan pengisian oleh ibu hamil; ibu juga melakukan pemeriksaan kehamilan oleh dokter di Puskesmas; sebelum melakukan kunjungan antenatal ibu sudah membuat janji terlebih dahulu; ibu hamil sudah mendapatkan vaksinasi COVID-19 bertujuan untuk melindungi diri dan janinnya.

\section{Ucapan Terima Kasih}

Ucapan terimakasih kami sampaikan kepada pembimbing dan responden semua pihak yang ikut berpartisipasi dalam penelitian ini.

\section{Daftar Pustaka}

Aliyanto, W., \& Rosmadewi, R. (2017). Pengetahuan ibu hamil tentang Program Perencanaan Persalinan Dan Pencegahan Komplikasi (P4k) pada Antenatal Care. Jurnal Ilmiah Keperawatan Sai Betik, 10(1), 90-96.

Hanum, R., \& Safitri, M. E. (2018). Hubungan pengetahuan dan sikap ibu hamil tentang pemanfaatan buku KIA di puskesmas Namu Ukur. Jurnal Bidan 
Komunitas, 1(3), 152-160.

Kementrian Kesehatan RI. (2016). Asuhan

Kebidanan Kehamilan. BPPSDM.

Kementrian Kesehatan RI. (2020a). Pedoman Pelayanan Antenatal, Persalinan, Nifas, dan Bayi Baru Lahir di Era Adaptasi Kebiasaan Baru.

Kementrian Kesehatan RI. (2020b). Pedoman Pencegahan dan Pengendalian Coronavirus Disease (COVID-19).

Kementrian Kesehatan RI. (2020c). Protokol Petunjuk Praktis Layanan Kesehatan Ibu Dan Bayi Baru Lahir Selama Pandemi Covid-19.

Lucia, S., Purwandari, A., \& Pesak, E. (2015). Pengaruh pelaksanaan kelas ibu hamil terhadap pengetahuan tentang persiapan persalinan. Jidan (Jurnal IImiah Bidan), 3(1), 61-65.

Mahayati, N. M. D., Hernowo, B., \& Judistiani, D. T. (2013). Pengetahuan, sikap, dan praktik penggunaan buku Kesehatan ibu dan anak pada anak umur 3-5 tahun Di kota denpasar. Program Studi Magister Kebidanan Fakultas Kedokteran Universitas Padjadjaran ....

Novitasari, R. (2017). Analisis Pelaksanaan Anc Terpadu Dalam Ketepatan Deteksi Dini Penyakit Penyerta Kehamilan Di Puskemas Imogiri 1 Bantul Daerah Istimewa Yogyakarta. Universitas' Aisyiyah Yogyakarta.

Refiani, D., Dewi, Y. I., \& Utami, S. (2021). Gambaran Perilaku Ibu Hamil dalam Melakukan Antenatal Care saat Pandemi Covid-19 di Puskesmas Rawat Inap Sidomulyo Kota Pekanbaru. Health Information: Jurnal Penelitian, 13(2).

RSUP Sarjito. (2021). Vaksinasi Covid-19 pada Ibu Hamil.

Sistiarani, C., Gamelia, E., \& Sari, D. U. P. (2014). Fungsi pemanfaatan buku KIA terhadap pengetahuan kesehatan ibu dan anak pada ibu. Kesmas: Jurnal Kesehatan Masyarakat Nasional (National Public Health Journal), 8(8), 353-358.

Tristanti, I., \& Kulsum, U. (2021). Potret Perilaku Pemeriksaan Kehamilan Di Masa Pandemi Covid 19. MOTORIK Jurnal IImu Kesehatan, 16(1), 17-23. 